\title{
PENDIDIKAN MULTIKULTURAL: SUATU KONSEP, PENDEKATAN DAN SOLUSI
}

\author{
Kuswaya Wihardit (kuswaya@ut.ac.id)
}

\begin{abstract}
Indonesia is a plural nation which consists of different ethnics, races, languages, customs, religions, and cultures. Indonesian society is also recognized as multicultural society with diversed background of cultures and religions. Conceptually, multiculturalism refers to country profile as a plural nation and multicultural society. Citizens would appreciate plurality and multiculturalism based on the equity principle.Multiculturalism as a concept of diversity and equity should be accomodated in the national education system. It should be reflected in the curriculum. Besides, the school has opportunity to develop its school curriculum (KTSP) integrating multicultural elements. Citizenship Education subject has the functions to integrate and develop multiculturalism issues in selected topics such as unity, equity, human rights, democracy, justice, and law. Other subjects integrate the issues into the teaching and learning process focusing issues of gender, ethnicity, and religion. Multicultural education is intended for develoving national character which promote students interactivity of different social cultural background. It develops in students emphaty through the observation of their attitude, perceptions, and views. In addition, it also develops student appreciation of multicultural differences, values, dan needs.
\end{abstract}

Keywords: multikulturalisme, PKN multicultural pluralisme,

Indonesia adalah bangsa majemuk yang terdiri dari berbagai suku bangsa, ras, bahasa, adat istiadat, agama dan budaya. Masyarakat Indonesia juga dikenal sebagai masyarakat multikultural karena anggotanya terdiri dari berbagai latar belakang agama dan budaya yang beragam. Indonesia merupakan bangsa multikultural dan majemuk, oleh karena itu bangsa Indonesia dapat disebut bangsa yang bersifat multikulturalisme. Secara konseptual sebenarnya multikulturalisme tidak sama dengan konsep keberagaman atau keanekaragaman. Konsep multikuluralisme selain mengandung unsur keberagaman agama dan budaya juga mengandung unsur kesedarajatan.

Konsep kesedarajatan harus dipandang sebagai adanya penghargaan terhadap derajat sesama warga negara sekalipun berbeda suku, adat istiadat, bahasa, ras, agama dan budayanya. Kesederajatan berarti adanya persamaan dan penghargaan terhadap hak asasi manusia (HAM), keadilan, hukum, potiltik dan budaya. Jadi konsep multikulturalisme menunjuk kepada adanya kesederajatan dalam keberagaman.

Multikulturalisme merupakan kekayaan bangsa yang tak ternilai harganya, sebagai potensi yang harus dikembangkan dan dibina. Sebaliknya apabila keberagaman ini tidak dimanfaatkan, dan dibina secara benar akan berkembang menjadi sesuatu yang menakutkan. Oleh karena itu, pendidikan yang berbasis multikulturalisme merupakan suatu keharusan dan apabila tidak dilakukan saat ini akan berubah menjadi malapetaka, pendidikan multikultural adalah "conditio cine quanon". Dulu keberagaman merupakan kekayaan bangsa yang paling dibanggakan, dibangun atas dasar tujuan dan kepentingan bersama yaitu kemerdekaan Indonesia. Saat ini, keberagaman sering 
dipandang sebagai perbedaan, perbedaan semakin dipertajam dan sering dimanfaatkan sebagian orang untuk memenuhi ambisi dan kepentingan pribadi atau golongannya. Ini menimbulkan konflik horizontal yang menyebabkan terpuruknya bangsa Indonesia, kerusuhan terjadi dimana-mana. Di Kalimantan Barat terjadi konflik etnik yang menyebabkan korban jiwa yang tak terhitung jumlahnya. Di Ambon dan Poso terjadi konflik antar penganut agama yang hampir menyeret bangsa ini ke jurang kehancuran. Di Papua sering terjadi perang antar suku yang menelan banyak korban jiwa, dan ini dianggap suatu tradisi untuk mempertahankan gengsi dan prestise.

Akhir-akhir ini konflik tersebut mengalami perubahan yang cukup signifikan, bukan semata terjadi karena perbedaan agama, etnik atau budaya, tetapi konflik terjadi karena perbedaan ideologi dan kepentingan. Tawuran dan bentrokan terjadi di mana-mana, antar pendukung kesebelasan sepak bola, tawuran antar mahasiswa, tawuran antar pelajar, dan tawuran antar penonton pagelaran musik. Ini menunjukkan bahwa rasa kebersamaan warga masyarakat sudah hilang, yang ada perbedaan idelogi dan kepentingan, apabila berbeda kepentingan dan ideologi dianggap lawan.

Keberbedaan kepentingan, golongan dan idologi ini semakin tajam dan mengarah pada konflik antar kelompok. Kelompok yang satu tidak mau lagi hidup berdampingan dengan kelompok lainnya. Keberagaman yang semula menjadi kebanggaan berubah menjadi suatu yang menakutkan, yaitu terganggunya stabilitas nasional dan disintegrasi bangsa. Ingat ketika peristiwa Monas, kelompok yang satu bentrok dengan kelompok lain yang sebenarnya mereka mempunyai keyakinan dan agama yang sama. Sering terjadi bentrokan antar warga kampung tertentu dengah kelompok warga kampung lainnya yang hanya dipisahkan oleh jalan raya. Bukankah diantara kelompok warga itu agamanya sama, bahasanya sama, dan etnisnya juga ada yang sama?.

Bangsa Indonesia adalah bangsa multikultural, dan plural terdiri dari masyarakat yang sangat beragam baik etnik, adat istiadat, bahasa, budaya, agama dan golongan. Masing-masing golongan masyarakat mempunyai karakteristik dan kepentingan yang berbeda-beda. Bagaimana upaya pendidikan jangan sampai konflik dan kerusuhan seperti ini berkelajutan? Salah satu upaya tersebut adalah melalui pendidikan. Karakteristik masyarakat multikultural harus tercermin dalam sistem pendidikan nasional, yaitu pendidikan yang mengakomodasi multikulturalisme dan pluralisme sesuai dengan tuntutan undang-undang.

Artikel ini ditulis untuk membantu pembaca menangkap butir-butir penting materi pendidikan multikultural, seperti berikut.

1. Pembaca memiliki pemahaman tentang multikulturalisme sebagai suatu konsep, substansi, dan sumber masalah.

2. Pembaca mempunyai pemahaman yang mendalam tentang pendidikan multikultural sebagai solusi dalam memecahkan berbagai permasalahan masyarakat multikultural.

3. Pembaca dapat memahami fungsi PKN sebagai mata pelajaran yang berfungsi untuk mengintegrasikan pendidikan multikultural.

\section{Pendidikan multikultural}

Multikulturalisme adalah "konsep pembudayaan, dan oleh karena proses pendidikan adalah proses pembudayaan, maka masyarakat multikultural dapat diciptakan melalui proses pendidikan" (HAR Tilaar, 2004). Pendidikan dan pembudayaan merupakan suatu proses pembentukan karakter bangsa dan warga negara. Pendidikan multikultural adalah pendidikan yang berbasis multikulturalisme. Tobroni dan kawan-kawan dalam bukunya Pendidikan Kewarganegaraan (2007) menyatakan bahwa Pendidikan multikultural dapat dilihat dalam tiga hal yaitu: 1) Pendidikan multikultural sebagai sebuah konsep atau idea, 2) pendidikan mutikultural sebagai suatu gerakan, 
dan 3) pendidikan multikultural sebagai sebuah proses. Oleh karenanya pendidikan multikultural memerlukan pengkajian yang mendalam, pengisian dan pengayaan konsep yang sempurna, dan penerapan yang cermat .

Sebagaimana telah dikemukakan bahwa bangsa Indonesia terdiri dari berbagai ragam suku bangsa, ras, bahasa, adat istiadat, budaya, agama dan golongan. Oleh karena itu, sistem pendidikan nasional juga harus mengakomodasi kemajemukan dan keragaman budaya tersebut. Keberhasilan pendidikan ditentukan oleh seberapa besar kepedulian pendidikan terhadap masalah pluralisme (kemajemukan) dan multikulturalisme (keragaman budaya, agama dan kesederajatan) ini. Hal ini disebabkan karena pendidikan merupakan proses pembudayaan atau enkulturasi, suatu proses untuk mentasbihkan seseorang mampu hidup dalam suatu budaya tertentu (Zamroni, 2001). Di sisi lain pendidikan juga memiliki peran sebagai culture heritage, yaitu sebagai pewarisan kebudayaan kepada generasi muda. Oleh karena itu, generasi tua harus dapat mewariskan sesuatu yang baik terhadap generasi berikutnya.

Pendidikan Nasional pada masa yang lalu, belum banyak mengadopsi kemajemukan dan keberagaman budaya. Pendidikan saat itu tidak dirancang dan bukan dalam kapasitas untuk mengantisipasi dan menanggulangi masalah yang disebabkan oleh perbedaan budaya, perbedaan kepentingan, perbedaan golongan, dan kesalahpahaman antarbudaya atau benturan antar golongan dan kepentingan. Sekalipun belum ada mata pelajaran pendidikan multikultural, atau pendidikan multikultural tidak tersurat dalam kurikulum sekolah, namun pendidikan dapat mengakomodasikan multikulturalisme dalam kurikulum atau mengintegrasikan pendidikan multikultural dalam mata pelajaran yang sesuai seperti PKN, dan mata pelajaran IPS.

Menurut Undang-undang Nomor 20 tahun 2003, tentang Sistem Pendidikan Nasional, Pasal 4 mulai butir (1) sampai dengan butir (6) menunjukkan bahwa multikulturalisme menjadi landasan bagi penyelenggaraan pendidikan di Indonesia. Oleh karena itu, menyelenggarakan Pendidikan Multikultural menjadi kewajiban sekolah sesuai dengan bunyi Pasal 4 butir (1) bahwa: "Pendidikan diselenggarakan secara demokratis dan berkeadilan serta tidak diskriminatif dengan menjunjung tinggi hak asasi manusia, nilai keagamaan, nilai kultural, dan kemajemukan bangsa".

Dalam Pasal 36 butir (3) berbunyi bahwa: Kurikulum disusun sesuai dengan jenjang pendidikan dalam kerangka Negara Kesatuan Republik Indonesia dengan memperhatikan:

a. peningkatan iman dan takwa;

b. peningkatan akhlak mulia;

c. peningkatan potensi, kecerdasan, dan minat peserta didik;

d. keragaman potensi daerah dan lingkungan;

e. tuntutan pembangunan daerah dan nasional;

f. tuntutan dunia kerja;

g. perkembangan ilmu pengetahuan, teknologi, dan seni;

h. agama;

i. dinamika perkembangan global; dan

j. persatuan nasional dan nilai-nilai kebangsaan.

Kalau diperhatikan bunyi pasal-pasal tersebut, pemerintah Indonesia memberikan kesempatan untuk menyelenggarakan pendidikan berbasis multikulturalisme yaitu pendidikan multikultural. Pendidikan nasional memberikan landasan bahwa dalam menyelenggarakan pendidikan tidak diskriminatif, menjunjung tinggi hak asasi manusia, nilai keagamaan, nilai kultural 
dan kemajemukkan bagsa. Ini menunjukkan bahwa pendidikan di negeri kita harus membawa pesan dan berlandaskan pendidikan multikultural.

Lebih lanjut dijelaskan melalui Pasal 36 butir (3), bahwa kurikulum disusun dengan memperhatikan keragaman potensi daerah dan lingkungan. Lingkup bahasan harus menjangkau dinamika perkembangan global yang mengantisipasi masalah-masalah keduniaan. Ini membuktikan bahwa pendidikan multikultural mendapatkan tempat yang seharusnya dalam kurikulum sekolah. Sekolah mempunyai kewenangan untuk mengembangkan Kurikulum Tingkat Satuan Pendidikan (KTSP) sesuai dengan kebutuhan, lingkungan dan kondisi sekolah. Sekolah dapat mengintegrasikan pendidikan multikultural ke dalam mata pelajaran di sekolah terutama mata pelajaran PKN dan IPS, bahasa dan sebagainya.

Menurut Undang-undang No 20 tahun 2003, tentang Sistem Pendidikan Nasional, pendidikan memiliki fungsi untuk "mengembangkan kemampuan dan membentuk watak serta peradaban bangsa yang bermartabat dalam rangka mencerdasakan kehidupan bangsa, bertujuan untuk berkembangnya potensi peserta didik agar menjadi manusia beriman dan berakhlak mulia, sehat, berilmu, cakap, kreatif, mandiri, dan menjadi warganegara yang demokratis serta bertnggung jawab". Tuntutan fungsi pendidikan itu menghendaki warga negara yang memiliki watak, dan berakhlak mulia, yang demokratis dan mertanggung jawab. Oleh karena itu, pendidikan multikultural merupakan tuntutan pendidikan nasional, karena pendidikan multikultural sesuai dengan fungsinya sebagai pembentukan watak warga negara yang diarahkan pada kerukunan antar budaya, dan learning to live together (UNESCO).

Pemerintah dalam hal ini Departemen Pendidikan Nasional telah mengeluarkan kebijakan sesuai dengan paradigma baru dalam pendidikan, yaitu merancang kurikulum masa depan yang berorientasi pada learning to be, learning to know, learning to do, dan learning to live together. Learning to live together merupakan usaha untuk merespons berbagai permasalahan yang disebabkan oleh adanya keberagaman dan kemajemukkan yang dipertajam oleh perbedaan. Dalam kaitannya dengan multikulturalisme pendidikan diarahkan untuk memberikan bekal kepada anak didik agar dapat hidup dalam masyarakat majemuk yang memiliki budaya yang sangat beragam. Untuk bisa hidup bersama, berdampingan dengan sesama warga negara lainnya walaupun berbeda kultur, agama, etnik dan golongannya. UNESCO dalam sidangnya pada bulan Oktober 1999 di Geneva (Deddy, 2000) merumuskan sebagai berikut:

1. Pendidikan seyogyanya mengembangkan kemampuan untuk mengakui dan menerima nilai-nilai yang ada dalam kebhinnekaan baik pribadi, jenis kelamin, masyarakat dan budaya serta mengembangkan kemampuan untuk berkomunikasi, berbagi dan bekerja sama dengan yang lain.

2. Pendidikan sebaiknya menumbuhkan solidaritas dan kesamaan pada tataran nasional dan internasional, dalam perspektif pembangunan yang seimbang dan lestari.

Hasil sidang UNESCO tersebut dapat dijadikan acuan agar pendidikan mulai memperhatikan keberagaman budaya sebagai salah satu aspek yang dijadikan dasar untuk membahas kebijakan pendidikan. Pendidikan multikultural adalah tuntutan sesuai dengan kondisi dan kebutuhan masyarakat. Oleh karena itu perlu dikaji secara seksama mengenai konsep, sistem dan implementasinya dalam dunia pendidikan di Indonesia.

Pendidikan multikultural erat kaitannya dengan pengembangan karakter warga negara Indonesia sebaga anggota masyarakat pluralism, dan multikulturalisme dalam tatanan yang 
demokratis dan bertanggung jawab. Dengan demikian, dalam diri siswa akan ditanamkan hal-hal seperti berikut:

1. Hubungan yang akrab dengan sesama siswa yang memiliki latar belakang sosial budaya yang beraneka ragam.

2. Sikap berempati siswa dengan cara mengamati sikap, pandangan, perasaan dan persepsi siswa lain yang berbeda latar belakang sosial budayanya.

3. Rasa menghormati dan menghargai nilai budaya dan kepentingan yang beragam sebagai kekayaan bangsa yang harus dijaga kelestariannya.

Tobroni dkk (Tobroni, 2007) menyatakan bahwa "Pendidikan Multikutural" adalah pendidikan yang memberikan kesempatan pada semua siswanya tanpa memandang jenis kelamin , kelas sosial, etnis, ras, agama, dan budayanya. Walaupun pengertian tersebut sangat sederhana, pendidikan multikultural harus diberi makna dan sesuai dengan fungsi pendidikan nasional. Gorski dan Colvert dalam Tobroni mendefinisikan Pendidikan Multikultural sebagai berikut.

- Setiap siswa harus mempunyai kesempatan yang sama dalam mengembangkan potensi dirinya;

- Mempersiapkan setiap siswa untuk berpartisipasi secara kompeten dalam masyarakat interbudaya;

- Guru dipersiapkan agar dapat membantu belajar setiap siswa secara efektif tanpa memandang latar belakang budaya yang berbeda;

- Sekolah harus berpartisipasi aktif dalam mengakhiri segala bentuk penindasan;

- Pendidikan harus berpusat pada siswa dan terbuka terhadap aspirasi dan pengalaman siswa.

Pendidikan multikultural berorientasi pada aktivitas siswa, dan perilaku siswa banyak dipengaruhi oleh budayanya. Oleh karena itu, pendidikan multikultural berupaya membantu siswa mengembangkan semua potensi sebagai pelajar dan anggota masyarakat.

Untuk dapat mengintegrasikan pendidikan multikultural dalam pelajaran di sekolah terutama dalam mata pelajaran PKN, alangkah baiknya dikemukakan Permendiknas Nomor 22 tah 2006, tentang ruang lingkup mata pelajaran PKN untuk pendidikan dasar dan menengah, seperti berikut.

1. Persatuan dan kesatuan bangsa, meliputi; hidup rukun dalam perbedaan, cinta lingkungan, kebanggaan sebagai bangsa Indonesia, sumpah pemuda, keutuhan negara kesatuan Republik Indonesia, partisipasi dalam pembelaan negara, sikap positif terhadap negara kesatuan RI, keterbukaan dan jaminan keadilan.

2. Norma, hukum dan aturan, mencakup; tertib dalam kehidupan keluarga, tata tertib di sekolah, norma yang berlaku di masyarakat, peraturan-peraturan daerah, norma-norma dalam kehidupan berbangsa dan bernegara, sisem hukum dan peradilan nasional, hukum dan peradilan internasional.

3. Hak asasi manusia (HAM) meliputi; hak dan kewajiban anak, hak dan kewajiban anggota masyarakat, instrumen nasional dan internasional HAM, pemajuan-penghormatan dan perlindungan HAM.

4. Kebutuhan warganegara meliputi; hidup gotong royong, harga diri sebagai masyarakat, kebebasan berorganisasi, mengeluarkan pendapat, mengahargai keputusan bersama, prestasi diri, dan persamaan kedudukan warga negara,

5. Konstitusi negara, meliputi; proklamasi kemerdekaan dan konstitusi yang pertama, konstitusi yang pernah digunakan Indonesia, hubungan dasar negara dengan konstitusi. 
6. Kekuasaan dan politik, meliputi; pemerintahan desa dan kecamatan, pemerintahan daerah otonomi, pemerintah pusat, demokrasi dan sistem politik, budaya politik, budaya demokrasi menuju masyarakat madani, sistem pemerintahan, pers dalam masyarakat demokrasi.

7. Pancasila meliputi; kedudukan Pancasila sebagai dasar negara dan ideologi negara, proses perumusan Pancasila sebagai dasar negara, pengamalan nilai-nilai Pancasila dalam kehidupan sehari-hari, Pancasila sebagai ideologi terbuka.

8. Globalisasi meliputi; globalisasi di lingkungannya, politik luar negeri Indonesia di era globalisasi, dampak globalisasi, hubungan internasional dan organisasi internasional, dan mengevaluasi globalisasi.

Lingkup materi untuk pendidikan dasar dan menengah tersebut cukup memberikan gambaran dan landasan bagi diintegrasikannya pendidikan multikultural di sekolah. Sekolah harus meramu dan mengemasnya ke dalam pelajaran PKN melalui lingkup materi persatuan dan kesatuan, norma, hukum dan aturan, HAM, kebutuhan warga negara, kekuasaan dan politik, Pancasila, dan lingkup globalisasi. Ke dalam lkingkup ini dapat diintegrasikan pendidikan multi kultural sehingga terciptalah PKN berbasis multikultural.

\section{Pembelajaran Pendidikan Kewarganegaraan berbasis Multikultural}

Dalam bagian ini pembahasan diarahkan terhadap prinsip-prinsip pembelajaran PKN dengan mengintegrasikan pendidikan multikultural, yaitu pembelajaran yang mencerminkan dan bermuatan substansi yang mendukung dan berbasis multikulturalisme. Di sini diuraikan peran pembelajaran PKN dalam pembelajaran berbasis multikultural.

Dalam pembelajaran yang menggunakan pendekatan multikultural, proses pembelajaran menekankan pada bagaimana memperlakukan siswa yang berbeda latar belakang sosial budaya dan kepentingannya. Dalam proses pembelajaran siswa dilatih untuk berpikir kritik, analitik, dan demokratis sehingga mereka dapat menemukan konsep, prinsip, dan nilai. Di sini dipelajari peran pendidikan dan proses pembelajaran PKN yang berkaitan dengan materi multikulturalisme. PKN mempunyai peran penting untuk mempersiapkan anak didik agar dapat mengatasi berbagai kesulitan dan permasalahan yang mereka temukan dalam masyarakat multikultural, serta menghormati keberbedaan sosial, kultural dan keberagaman budaya.

Perlu ditekankan kembali bahwa keanekaragaman tanpa adanya kesedarajatan bukan multikulturalisme, oleh karena itu "pendidikan multikultural" dengan pengertian di atas harus dipandang sebagai upaya untuk meningkatan pemahaman siswa tentang keanekaragaman dan kesederajatan kultur. Siswa harus memahami bahwa tidak ada perbedaan nilai dan budaya antara etnik, agama, adat istiadat, antara orang Jawa, Sunda, Batak, Dayak, Sasak, Bugis, Madura dan seterusnya. Untuk dapat memahami konsep ini terlebih dahulu siswa harus memahami konsep hak asasi manusia (HAM), demokrasi, keadilan, hukum, dan politik.

Sekolah sebagai bagian integral dari masyarakatnya memiliki siswa yang karakteristiknya beragam sebagai cerminan dari masyarakatnya. Sekolah di kota-kota besar merupakan contoh yang paling tepat menunjukkan keberagaman budaya, agama, etnis, bahasa dan sebagainya. Sekolah harus menaruh perhatian yang besar terhadap masalah ini, karena undang-undang dan kurikulumya sudah memfasilitasi ke arah pendidikan multiltural. PKN berbasis pendidikan multikultural tidak bermaksud untuk menyamakan atau menyatukan budaya yang sangat beraneka ragam tersebut. PKN berbasis pendidikan multikultural bertujuan untuk memberikan bekal pengetahuan dan pengalaman pada siswa agar mereka menyadari bahwa walaupun berbeda sosial dan budayanya, 
namun tetap satu yaitu sebagai warga negara Indonesia, sebagai makhluk ciptaan Tuhan, dan memiliki hak dan kewajiban yang sama, dan sederajat dalam negara kesatuan Republik Indonesia. Oleh karena itu, tidak ada seorang pun warga negara yang lebih tinggi atau lebih rendah derajatnya dari warga negara lainnya.

PKN berbasis pendidikan multikutural harus tetap menghargai keberbedaan, baik perbedaan individual (fisik, jenis kelamin, umur, warna kulit, dan tinggi badan), maupun perbedaan budaya, sosial, agama, bahasa, etnik dan golongan. Perbedaan ini harus tetap dihargai. Oleh karena itu, perlakuan yang diberikan juga harus mempertimbangkan latar belakang budayanya. PKN tidak boleh menggeneralisasikan atau menyamaratakan orang yang berbeda-beda. Untuk ini maka PKN memegang peranan yang sangat penting.

Jadi, PKN berbasisis pendidikan multikultural adalah pendidikan yang mampu menanamkan prinsip multikulturalisme yang merupakan suatu realita dalam kehidupan bangsa Indonesia. Prinsip dalam pendidikan multikultural adalah menanamkan kesadaran akan pentingnya rasa persatuan dan kesatuan bangsa, dan mengembangkan kesadaran untuk dapat menghargai adanya kebhinnekaan, keberagaman dan kederajatan dalam masyarakat dan bernegara.

PKNI ini mengandung tiga makna. Pertama, "multikuturalisme" sebagai sumber bahan belajar yang dapat diberikan di sekolah, yaitu memberikan pengetahuan tentang keberagaman budaya Indonesia sebagai materi pembelajaran di sekolah. Ini berkaitan dengan antara lain materi keberagaman budaya, keberagaman daerah, keberagaman agama, dan keberagaman adat istiadat. Kedua, menanamkan pemahaman dan sikap dalam hidup bermasyarakat, berbangsa dan bernegara. Oleh karena itu materi demokrasi, hukum, keadilan, kerukunan, kebijakan publik, dan Hak Asasi Manusia (HAM), menjadi materi pengayaan di sekolah. Ketiga, menerapkan sikap dan pembiasaan dalam kehidupan sehari-hari di sekolah seperti toleransi, berbuat adil, saling menghargai, saling menghormati, berempati, hidup rukun dan damai, dan demokratis..

Di lain pihak PKN berbasis pendidikan multikultural adalah suatu pendekatan yang digunakan guru dalam proses pembelajaran untuk menanamkan prinsip multikulturalisme. Multikulturalisme adalah suatu masyarakat yang warga masyarakatnya heterogin dan masing-masing mengembangkan tradisi dan interest mereka. Sementara itu mereka tetap dapat bekerja sama, dan saling tergantung satu sama lainnya dalam mewujudkan kehidupan kesatuan bermasyarakat dan bernegara. Fokus utama dalam masyarakat multikultural adalah adanya saling kerja sama, ketergantungan dan kesatuan bangsa. (Zamroni, 2001). Selanjutnya Tobroni dkk, menyatakan bahwa dalam masyarakat multikultural tetap mengutamakan kesamaan derajat, rasa persatuan dan kesatuan bangsa, tanpa harus mengorbankan identitas kelompok atau golongan tertentu.

Peran PKN berbasis pendidikan multikultural adalah untuk meningkatkan kesadaran masyarakat tentang pentingnya persatuan dan kesatuan bangsa. Sebagai suatu bangsa harus menyadari bahwa apa yang terjadi di masa mendatang akan sangat tergantung pada pendidikan saat ini. Apabila pendidikan memberikan tentang pentingnya kesatuan dan persatuan, di masa mendatang akan lahir masyarakat yang mencintai kesatuan dan persatuan. Apabila pendidikan tidak memberikan tentang budi pekerti, akan lahir masyarakat yang tidak santun dalam pergaulan di masyarakat. Jadi apa yang akan dihasilkan nanti akan sangat tergantung pada pendidikan yang diberikan saat ini, meminjam istilahnya Zamroni i disebut "Sosial Reproduction".

PKN sebagai mata pelajaran yang berusaha mengintegrasikan pendidikan multikultural ke dalamnya harus terus memperkaya materi sesuai paradigma baru yaitu bernapaskan keberagaman dan kesederajatan, baik dalam konten maupun dalam metode pembelajaran. Sesuai dengan paradigma baru tersebut, PKN memfokuskan diri pada pendidikan demokrasi dan Hak Asasi 
Manusia (HAM). Ini tidak berarti menyisihkan materi lain, materi PKN tersebut tetap ada, tetapi HAM dan demokrasi lebih mendapat pengayaan dan pendalaman. Hal ini disebabkan karena kehidupan berbangsa dan bernegara bangsa Indonesia saat ini sedang berubah menuju kehidupan yang demokratis yang menghargai hak asasi manusia.

Dalam lampiran Permendiknas No 22 tahun 2006 dinyatakan bahwa "mata pelajaran Pendidikan Kewargaannegara merupakan mata pelajaran yang memfokuskan pada pembentukan warga negara yang memahami dan mampu melaksanakan hak-hak dan kewajiban untuk menjadi warga negara Indonesia yang cerdas, terampil, dan berkarakter sesuai dengan Pancasila dan Undang-undang Dasar 1945". Oleh karena itu tujuan mata pelajaran PKN adalah agar peserta didik memiliki kemampuan berikut:

1. Berpikir secara kritis, rasional, dan kreatif dalam menangani isu-isu kewaranegaraan.

2. Berpartisipasi secara aktif dan bertanggung jawab, dan bertindak secara cerdas dalam kegiatan masyarakat, berbangsa, serta anti korupsi.

3. Berkembang secara aktif dan demokratis untuk membentuk diri sendiri berdasarkan karakterrkarakter masyarakat Indonesia agar dapat hidup bersama dengan bangsa-bangsa lain.

4. Berintegrasi dengan bangsa-bangsa lain dalam percatutan dunia secara langsung atau tidak langsung dengan memanfaatkan teknologi informasi dan komunikasi.

Dalam kurikulum PKN, terdapat beberapa pokok bahasan di mana materi pendidikan multikutural dapat diintegrasikan ke dalamnya. Pokok bahasan tersebut, antara lain seperti berikut.

1. Persatuan dan kesatuan.

2. Cinta tanah air.

3. Persamaan derajat.

4. Persamaan hak dan kewajiban.

5. Kerukunan.

6. Keadilan.

7. Gotong-royong.

Dalam proses pembelajaran PKN, sebagaimana halnya pada pembelajaran umumnya diarahkan pada aktivitas yang terpusat pada siswa, dengan cara menciptakan suasana kelas yang hidup, dan demokratis. Untuk mengenali ciri bahwa suasana kelas demokratis bahwa guru tidak lagi menjadi faktor yang sangat dominan di kelas, siswa bebas mengeluarkan pendapatnya, serta adanya pembahasan controversial issues yaitu isu dan masalah yang terjadi di masyarakat.

Dalam pembelajaran PKN yang terkait dengan materi pendidikan multikultural dapat dilakukan melalui dua strategi, yaitu pertama multikultutralisme sebagai substansi dan sumber belajar, dan kedua multikulturalisme sebagai stategi perekat persatuan dan kesatuan bangsa dengan menempatkan kesederajatan sebagai persamaan hak.

Pembelajaran PKN dengan muatan multikulturalisme berusaha menciptakan suasana pembelajaran yang nyaman, penuh keakraban, dan saling menghargai. Untuk ini guru harus memilih pendekatanh dan metode yang merangsang daya berfikir siswa, menumbuhkan kerjasama dan bervariasi, misalnya menggunakan pendekatan pemecahan masalah, pendekatan CTL (pembelajaran kontekstual), pendekatan PAKEM, metode vaue clarification technique, metode inkuiri, teknik bertanya dengan menggunakan teknik bertanya bervariasi dari mulai "low order question" (pertanyaa tingkat rendah) dan "high order question" (pertanyaan tingkat tinggi). Pembelajaran 
dengan menggunakan pendekatan PAKEM dapat diterapkan sebagai upaya membuat siswa senang belajar.

Diilhami oleh pendapatnya Eric Jansen dalam bukunya "Brain Based Learning" yang dikutip Kompas tanggal 21 Desember 2008 mengemukakan tiga strategi pembelajaran yang cocok untuk ini yaitu menciptakan suasana atau lingkungan yang mampu merangsang kemampuan berpikir.

a. Menciptakan susana atau lingkungan yang mampu merangsang kemampuan berpikir siswa. Guru memberikan soal-soal materi pelajaran yang mampu memfasilitasi kemampuan berpikir siswa, dengan dibuat seatraktif mungkin. Ini harus diisi dengan materi PKN sebagai contoh mengapa penggunaan warna-warna di daerah Batak dan Toraja mirip, yiatu warna merah, hitam, dan putih sangat dominan.

b. Guru menciptakan suasana pembelajaran yang membuat siswa nyaman dan terlibat aktif belajar di dalamnya. Guru melakukan variasi dalam kegiatan pembelajaran seperti belajar di luar ruangan, diskusi kelompok, dan permainan yang menarik. Misalnya siswa ditugaskan mengamati keadaan masyarakat multikultural di pasar, dan bagaimana cara pergaulannya.

c. Guru menciptakan suasana aktif dan bermakna, yaitu berusaha menampilkan kegiatan yang mengaktifkan seluruh anggota badan siswa untuk beraktivitas misalnya mata untuk membaca dan mengamati, tangan untuk menulis dan menggunakan alat peraga, dan mulut untuk berdiskusi.

Guru dapat membentuk kelompok belajar yang anggotanya terdiri dari berbagai macam ragam budaya dan agama. Kelompok ini harus mencerminkan kedaan dan keberagaman masyarakat di sekitarnya. Dengan demikian siswa terlatih dan terbiasa dalam kondisi seperti itu.

\section{PENUTUP}

Pendidikan multikultural dapat dilakukan melalui tiga jalur pendidikan yaitu pendidikan dalam masyarakat (nonformal), pendidikan dalam keluarga (informal), dan pendidikan di sekolah (formal). PKN sebagai pelajaran dalam jalur pendidikan formal di sekolah, memberikan bekal pengetahuan dan pengalaman multikulturalisme kepada siswa bila mereka terjun ke masyarakat. Oleh karena itu multikulturalisme sebagai ciri utama masyarakat Indonesia, merupakan lingkup materi yang harus mendapat tempat dalam pelajaran PKN.

Yose Ortega mengatakan bahwa sekolah merupakan cermin masyarakatnya, apabila rusak masyarakatnya maka akan rusak pulalah sekolah (Zamroni, 2001). Oleh karena itu, perbaikan atau pembentukan karakter warga negara melalui PKN di sekolah harus diimbangi oleh pendidikan masyarakatnya. Di sini PKN menempatkan posisi sekolah sebagai social change agence (agen perubahan sosial).

Pendapat Ortega ini dapat dipahami karena sistem kehidupan yang ada dalam masyarakat akan banyak mempengaruhi kehidupan siswa. Siswa lebih banyak menghabiskan waktunya dalam masyarakat jika dibandingkan dengan di sekolah. Selain itu, yang menjadi kendala utama adalah tidak sinkronnya sistem yang ada di sekolah dengan di masyarakat. Sebagai contoh, siswa di sekolah dilarang berkelahi atau tawuran dan membuat onar, dan apabila melanggar ketentuan ini siswa akan dihukum. Tetapi apabila siswa ke luar dari sekolah, ia terlibat tawuran atau berkelahi di jalanan, siapa yang akan menghukum mereka? Ketidaksinkronan sistem ini akan mempengaruhi perilaku siswa.

PKN berbasis pendidikan multikultural merupakan paradigma baru yang harus disikapi sebagai konsep yang harus diajarkan di sekolah. Dalam proses pembelajaran, PKN harus 
mencerminkan multikulturalisme sebagai cerminan suatu masyarakat multikultural. Sekolah adalah bagian integral dari suatu masyarakat, yang tidak bisa dilepaskan dari kehidupan masyarakat. Oleh karena itu dalam proses pembelajaran, siswa harus "didekatkan" dengan masyarakat, kehidupan dan permasalahan masyarakat. Siswa harus terbiasa dan terlatih dalam menghadapi permasalahan dalam masyarakat, sehingga terlatih pula dalam memecahkan permasalahan masyarakat.

\section{REFERENSI}

Maulana, A. (1997). Komunikasi antarmanusia. Alih bahasa dari Joseph, A DeVito. Human communication. Jakarta: Professional Books.

Yaqin, A. (2005), Pendidikan Multikultural,:Qross-understanding untuk demokrasi. Yogyakarta: Pilar Media.

Branson, M.S. et al. (1999). Belajar civic education dari Amerika, Yogyakarta: LKIS.

Gautama,C. \& Marbun, BN (Ed.), (2000), Hak asasi manusia: Penyelenggaraan negara yang baik dan masyarakat warga. Komisi nasional hak asasi manusia: Jakarta.

Mulyana, D. \& Rakhmat, J. (Eds.). (2000). Komunikasi antarbudaya. Bandung: Remaja Rosdakarya

Rosyada, D. et al. (TIM UIN), (2003). Pendidikan kewargaan (Civica education): Demokrasi, hak asasi manusia dan masyarakat madani. Jakarta: ICCE UIN.

Glover, D. \& Sue L. (2002). Improving learning (terjemahan Willie Koen). Jakarta: Grasindo.

Tilaar, H.A.R. (2004). Multikulturalisme: Tantangan-tantangan global masa depan dalam transformasi pendidikan nasional. Jakarta: Lembaga Manajemen Universitas Jakarta.

Kincheloe, J.L. \& Skirley R.S. (2002). Changing multiculturalism. Philadelphia: Open University Press.

Kosasih, D.A. (1985). Strategi pengajaran afektif-nilai-moral, VCT dan Game dalam VCT. Jurusan PMPKN, IKIP Bandung.

Tilaar, HAR. (1998). Beberapa agenda reformasi pendidikan nasional, Dalam Perspektif abad ke-21 Jakarta: Penerbit Tera Indonesia.

Tobroni, et al. (2007). Pendidikan kewarganegaraan: Demokrasi, HAM, Civil Society, dan Multikutural. Malang: PuSAPoM.

Winataputra U. S, et al. (2006). Materi dan pembelajaran PKN SD. Jakarta: Universitas Terbuka. Zamroni. (2001). Pendidikan untuk demokrasi: Tantangan menuju civil society. Yogyakarta: Biography publishing. 